Article

\title{
Implementation of the Digital Sales Channel in the Coatings Industry
}

\author{
Eva Krhač Andrašec, Benjamin Urh, Marjan Senegačnik and Tomaž Kern *
}

check for updates

Citation: Krhač Andrašec, E.; Urh, B.; Senegačnik, M.; Kern, T.

Implementation of the Digital Sales Channel in the Coatings Industry.

Processes 2021, 9, 1168. https://

doi.org/10.3390/pr9071168

Academic Editor: Anet Režek Jambrak

Received: 31 May 2021

Accepted: 2 July 2021

Published: 5 July 2021

Publisher's Note: MDPI stays neutral with regard to jurisdictional claims in published maps and institutional affiliations.

Copyright: (c) 2021 by the authors. Licensee MDPI, Basel, Switzerland. This article is an open access article distributed under the terms and conditions of the Creative Commons Attribution (CC BY) license (https:/ / creativecommons.org/licenses/by/ $4.0 /)$.
Laboratory of Enterprise Engineering, Faculty of Organizational Sciences, University of Maribor, Kidričeva Cesta 55a, 4000 Kranj, Slovenia; eva.krhac1@um.si (E.K.A.); benjamin.urh@um.si (B.U.); marjan.senegacnik@um.si (M.S.)

* Correspondence: tomaz.kern@um.si; Tel.: +386-(0)4-23-74-279

\begin{abstract}
The development process in the coatings industry can be shortened by digital transformation, and its costs can be reduced using a technical enabler. However, formulators need up-to-date and comprehensive data on existing and potential ingredients to develop the formulation. We were curious about how to supply formulators with data. The idea was that suppliers of ingredients provide data using the "common enabling technology". We hypothesize that direct data entry compensates suppliers because they can shorten the sales process and increase sales. We used a survey to select key sales channels in the industry. Detailed process models were designed using structured interviews. We analyzed models using structural and operational indicators. Finally, we formed a new digital sales process and verified it. The results show that the digitally formatted sales process can be shortened by up to $32 \%$. Simultaneously, more potential customers can be accessed using the common technology. Existing sales channels would not be closed down. Nevertheless, the digital sales channel is expected to prove its worth over time and gradually increase its share. The suppliers of ingredients can thus avoid a radical process transformation and the immediate integration of additional information technology into the company information system in such an evolutionary way.
\end{abstract}

Keywords: digital sales channel; process analyses and improvement; digital transformation; technical enabler; coatings industry

\section{Introduction}

It has been proven that through the digital transformation of the paints and coatings development process, companies can shorten the throughput time of the development process [1]. In the same way and consequently, by reducing the number of repetitions in laboratory testing, it is possible to reduce the amount of waste generated during the development process [2]. When the process is digitally transformed using a technical enabler, it is also possible to reduce development costs [3].

For the successful digital transformation of development processes, it is necessary to have up-to-date and comprehensive data on possible (existing and potential) ingredients in the formulation that is the subject of development. The key question is how to provide data to the information-communication tool that is the enabler of digital transformation so that formulators could use it? Currently, there are several ways to obtain data: manual entry, transfer from own databases, scanning documents, and others [1]. Undoubtedly, the most effective and only rational way to capture data on ingredients is at the place of origin, with the developers and suppliers of ingredients [4].

Therefore, the idea is to ensure that suppliers provide data on ingredients they produce and place on the market. The data must be accessible so that the formulator in another company can use it in the development process without additional waiting and costs. The advantage of such an approach is obvious [1-3]. Furthermore, the technical conditions are already set as a technical enabler is available [5]. By using the technical enabler, the 
company could offer ingredients to formulators more efficiently and effectively. It is useful for the sale of ingredients at the beginning of the logistics chain in the production of goods, as well as for supply, development, and in manufacturing companies throughout the rest of the process. This is the reason why we named it "common technical enabler". The question is whether it is in the interest of the manufacturer and the supplier to provide information on the ingredients through this sales channel. We wonder about the benefits of implementing an additional sales channel. Are the benefits more significant than the effort that would be required? The question is also whether the existing sales channels are thus eliminated or if it would be possible to operate in parallel.

The purpose of the research is to determine whether digital transformation can shorten and reduce the sales process in the coatings industry, which would consequently mean higher process efficiency. At the same time, we want to determine whether the sales process can also be improved in terms of more effective access to detailed information on a broader range of potential customers, which would increase sales success.

Each process can be measured in terms of time, cost, productivity, quality [6], capital, and in comparison with the processes they replaced $[7,8]$. A condition for process analysis and the achievement of organizational goals is process modeling, which has gained importance since organizations and digitalization [9] put processes at the forefront [10,11]. Its importance is in describing processes and presenting the preparatory phase for improvement, business process reengineering, technology transfer, process standardization [11,12], and innovation [13]. The result of modeling is a business process model with which we can capture tasks, events, the state and logic of the process flow [14], as well as capture the activities of business systems [15].

Vanderfeesten et al. [16] and Cardoso [17] emphasize the importance of developing indicators for the automatic identification of complex process areas. A process indicator is a measurement that allows the quantification of process objects. It must be standard, simple, calculable, consistent, objective, and its automation is also desirable [17].

In the available relevant literature, we have identified various proposals for evaluating the efficiency of business processes. Business process evaluation from the perspective of model objects and the outcomes obtained in its execution prevails. Thus, two categories of indicators have been identified: operational and structural [18]. Three dimensions (time, cost, and quality) are usually defined for operational indicators, and different key performance indicators can be defined for each [19]. Their advantage is that they enable a quick (after execution) evaluation of the process execution and are able to compare it with the previous execution [20].

To achieve effective business process management, the fundamental area of research is the structural efficiency (complexity) of business processes [17,20], as it determines the probability of errors [21]. Structural efficiency indicators [18] are also called structural complexity indicators of the business process [17]. For easier understanding, we use the term "structural indicator" in the following sections. Process complexity is characterized by the number and complexity of activity connections, transitions, conditional and parallel branches, the existence of loops, roles, activity categories, types of data structures [17], and the dynamics of process change or development over time [22]. It is expressed by fundamental indicators defined by the number of main business objects (e.g., activities, events, operators, etc.) and derived indicators calculated based on fundamental indicators and indicators specific to each business process [11,20]. Rolón et al. [18] defined four main groups of structural indicators as [23]: process flow (activities, events, operators/decisions), links (feedback loops, links to other processes), positions, and support objects (documents, software tools, etc.). In the following years, the authors emphasized various aspects (properties) of structural complexity and defined several groups of indicators: structural complexity of activities, sequences of flows, the flow of information and resources [17,24]; size, connectivity, complexity [11,25,26]; complex behavior [25]; syntax rules [26]; modularity/structure and complexity of operators/process structure [25,26]. 
Because of the multiple divisions into groups, a single indicator is never appropriate as business processes consist of many objects $[17,27,28]$. We measure only one aspect with each indicator, and they need to be combined to provide comprehensive insight [28].

High complexity in business processes leads to poor understandability [14,17], errors, failures, and exceptions that lead to processes needing more time to develop, test, and maintain. Complexity is a sign of a fragile, inflexible, and hazardous process. In contrast, processes with a low degree of complexity can rapidly change and accept new products to meet the changing needs of stakeholders [17].

The advantage of structural indicators is that they provide an overview of the state of the organizational structure's adequacy, work formalization, entrusted competencies and responsibilities, flow complexity, labor division adequacy between activities, and connectivities of the business process [20]. Irani et al. [29] also cite as reasons for their identification the recognition of the essence of the problems of existing processes and the easier communication between positions in the planning of improvements and their implementation. Structural indicators help design and implement simpler, more reliable, and robust workflows and business processes [17]. However, monitoring process execution efficiency is easier as it requires less prior preparation than monitoring according to operational indicators [20].

Many studies have described the possibilities of using operational and structural indicators and their corresponding benefits in practice. As an example, we cite a study in which the authors measured the efficiency of the product development process in organizations using the following indicators [30]: time between idea creation and the start of production, the ratio between the number of employees and the number of tasks, the ratio between the number of messages and number of tasks, the number of tasks performed in one iteration of the process and the number of congestions in the process.

This article focuses on improving the sales process efficiency in the coatings industry in terms of structural indicators and the time dimension of operational indicators. In the following section (Section 2), the research procedure is described. Subsequently, the results of the research are presented (Section 3). The article is concluded with a discussion of the research (Section 4).

\section{Research Procedure}

For the research, procedures were prepared and carried out in six stages:

- Review of theoretical bases;

- Conducting a survey (identification of sales channels and determining their importance);

- Conducting structured interviews (modeling-As-Is sales processes);

- Business process analysis;

- A proposal to improve the process with the help of a common technical enabler and digital transformation of the sales channel process (modeling-To-Be sales process);

- Verification of the efficiency of the To-Be sales process.

Stage 1: First, we performed a theoretical review to verify existing sales channels and their activities. The results of the review are presented in Tables 1 and 2.

Stage 2: Based on the theoretical review, a survey questionnaire was prepared. The primary purpose was to determine which sales channels were being used in the coatings industry. The online survey analyzed companies from the coatings industry, and sellers and sales managers completed it on behalf of the companies. The survey was answered by 18 companies from the EU (Table 3). 
Table 1. Theoretical review of sales channels.

\begin{tabular}{|c|c|}
\hline References & Sales Channels \\
\hline Alba et al. [31] & $\begin{array}{l}\text { Supermarket, department store, category, catalog, internet retail, and } \\
\text { interactive home shopping. }\end{array}$ \\
\hline Payne and Frow [32] & $\begin{array}{l}\text { 1. Sales force (field account management, service, personal representation); } \\
\text { 2. Outlets (retail branches, stores, depots, and kiosks); } \\
\text { 3. Telephony (traditional telephone, facsimile, telex, call center contact); } \\
\text { 4. Direct marketing (direct mail, radio, traditional TV); } \\
\text { 5. E-commerce (e-mail, the Internet, interactive digital TV); } \\
\text { 6. M-commerce (mobile telephony, SMS and text messaging, WAP, and 3G } \\
\text { mobile services). }\end{array}$ \\
\hline Neslin et al. [33] & $\begin{array}{l}\text { Internet, ATM, call centers, retail, catalog, internet, direct e-mail, store, } \\
\text { telemarketing, direct selling. }\end{array}$ \\
\hline Neslin and Shankar [34] & $\begin{array}{l}\text { Channels typically include the store, the Web, catalog, sales force, third party } \\
\text { agency, call center and the like. }\end{array}$ \\
\hline Avery et al. [35] & Catalog channel, internet channel (websites), retail store. \\
\hline Verhoef et al. [36] & $\begin{array}{l}\text { Retail channels (store), online website, direct marketing, mobile channels (i.e., } \\
\text { smart phones, tablets, apps), social media customer touchpoints (mass } \\
\text { communication channels: TV, Radio, Print, C2C). }\end{array}$ \\
\hline Kannan et al. [37] & $\begin{array}{l}\text { Online, mobile and offline media and channels: search engines, display } \\
\text { advertisement, social media, e-mail, print ads, radio, TV ads, website, mobile } \\
\text { apps or sites, stores. }\end{array}$ \\
\hline Kannan [38] & $\begin{array}{l}\text { Online and mobile channels (apps), social channels, search engines, e-mail, } \\
\text { print catalog, TV. } \\
\text { Individual marketing channels, such as search, display, } \\
\text { e-mail, referral, and direct site. }\end{array}$ \\
\hline van Heerde et al. [39] & Online channel, physical store, mobile channel (app). \\
\hline Liu et al. [40] & $\begin{array}{l}\text { 1. Offline channels } \\
\text { (mainly physical stores and catalogs); } \\
\text { 2. Online channels (e-mail and websites); } \\
\text { 3. Mobile channels (mobile websites and apps); } \\
\text { 4. Other touchpoints (social media, word of mouth advertising, promotions, } \\
\text { and thank-you cards). }\end{array}$ \\
\hline Liu et al. [41] & Physical stores, online website, mobile website, apps. \\
\hline
\end{tabular}

Table 2. Theoretical review of sales channel activities.

\begin{tabular}{ll}
\hline \multicolumn{1}{c}{ References } & \multicolumn{1}{c}{ Sales Channel Activities } \\
\hline & 1. Generating sales leads; \\
2. Make the right sales contacts; & 3. Get sales appointments; \\
Nibusinessinfo.co.uk [42] & 5ales meeting; \\
& 5. Negotiate and close the sale; \\
6. Sales follow-up and relationship building. & 1. Comprising the sourcing of products; \\
& 2. Stockholding, inventory, and store merchandising; \\
3. Marketing effort, including branding; \\
4. Customer selection, picking, and payment; \\
5. Distribution of goods by or to the consumer. \\
1. Transport from supplier to DC; \\
2. Warehousing (receiving and storing, inventory, picking, \\
packing and consolidation); \\
3. Transport from DC to store; \\
4. Store activities (handling, inventory); \\
5. Home delivery.
\end{tabular}


Table 3. Table of companies with area of business, size, years in the industry, and responding person.

\begin{tabular}{|c|c|c|c|c|}
\hline Company & Area of Business & Size & $\begin{array}{l}\text { Years in the } \\
\text { Industry }\end{array}$ & Responding Person \\
\hline Company A & $\begin{array}{l}\text { Production of coatings, lacquers, } \\
\text { pigment pastes, and chemicals. }\end{array}$ & $\begin{array}{l}\text { Small-sized } \\
\text { enterprise }\end{array}$ & Since 1980 & $\begin{array}{l}\text { Director and Head of } \\
\text { Development }\end{array}$ \\
\hline Company B & $\begin{array}{c}\text { Production of abrasives, putties-body fillers, } \\
\text { primers, masking products, clear coats and } \\
\text { paints, uniMix paints, } \\
\text { hardeners, polishing system, bonding and sealing } \\
\text { products, body shop, } \\
\text { consumables tools and accessories, health and } \\
\text { safety products, car cleaning products, } \\
\text { technical aerosols, } \\
\text { promotional articles. }\end{array}$ & $\begin{array}{l}\text { Medium-sized } \\
\text { enterprise }\end{array}$ & More than 20 years & Head of Development \\
\hline Company C & $\begin{array}{c}\text { Production of titanium dioxide, } \\
\text { sulphuric acid, zinc wire, zinc alloys, zinc bars, } \\
\text { zinc anodes, recycled zinc, printing inks, } \\
\text { powder coating, } \\
\text { anti-corrosion coatings, copper } \\
\text { fungicides, sulfur fungicides, fertilizers, } \\
\text { phytopharmaceuticals, rubber coating. }\end{array}$ & $\begin{array}{l}\text { Large-sized } \\
\text { enterprise }\end{array}$ & Since 1873 & Sales Manager \\
\hline Company D & $\begin{array}{l}\text { Sales, marketing, and logistics of } \\
\text { specialty chemicals and ingredients. }\end{array}$ & $\begin{array}{l}\text { Large-sized } \\
\text { enterprise }\end{array}$ & Since 1995 & Marketing Manager \\
\hline Company E & $\begin{array}{l}\text { Production of decorative coatings, } \\
\text { industrial paints for wood and metals, } \\
\text { car refinish program, road paints, } \\
\text { resins, powder coatings. }\end{array}$ & $\begin{array}{l}\text { Medium-sized } \\
\text { enterprise }\end{array}$ & Since 1844 & $\begin{array}{l}\text { Head of Coating } \\
\text { Resins Sales }\end{array}$ \\
\hline Company F & $\begin{array}{l}\text { Coatings for wood and metals, wall } \\
\text { paints, plasters. }\end{array}$ & $\begin{array}{l}\text { Small-sized } \\
\text { enterprise }\end{array}$ & Since 1995 & Sales Manager \\
\hline Company G & $\begin{array}{l}\text { Distributor and agent for raw materials and } \\
\text { chemicals—-they are concerned with products } \\
\text { used in construction, coatings, detergent, } \\
\text { cosmetics, rubber and plastic, food and feed. }\end{array}$ & $\begin{array}{l}\text { Micro-sized } \\
\text { enterprise }\end{array}$ & Since 1993 & Director \\
\hline Company H & Distributor for coatings, lacquers, and chemicals. & $\begin{array}{l}\text { Small-sized } \\
\text { enterprise }\end{array}$ & Since 1997 & Sales Manager \\
\hline Company I & $\begin{array}{l}\text { Production of coatings for impregnation and } \\
\text { protection of wood, stone, and other building } \\
\text { materials, grouts, waterproofing } \\
\text { coatings, cleaners. }\end{array}$ & $\begin{array}{l}\text { Micro-sized } \\
\text { enterprise }\end{array}$ & Since 2014 & Sales Manager \\
\hline Company J & Distribution and selling of various chemicals. & $\begin{array}{l}\text { Micro-sized } \\
\text { enterprise }\end{array}$ & Since 2011 & $\begin{array}{l}\text { Business } \\
\text { Development } \\
\text { Manager }\end{array}$ \\
\hline Company K & $\begin{array}{l}\text { Production of paints and coatings, performance } \\
\text { applications, and composites. }\end{array}$ & $\begin{array}{l}\text { Large-sized } \\
\text { enterprise }\end{array}$ & Since 1961 & $\begin{array}{l}\text { Business Developer } \\
\text { and Innovation } \\
\text { Leader }\end{array}$ \\
\hline Company L & $\begin{array}{l}\text { Specialty chemicals for paints, coatings, } \\
\text { adhesives, plastics, building materials: } \\
\text { defoamers, powder additives, wetting and } \\
\text { dispersion agents, mineral flame retardants, } \\
\text { thickeners and rheology, additives, pigments } \\
\text { and fillers. }\end{array}$ & $\begin{array}{l}\text { Small-sized } \\
\text { enterprise }\end{array}$ & Since 1947 & Managing Director \\
\hline Company M & Production of complex inorganic color pigments. & $\begin{array}{l}\text { Medium-sized } \\
\text { enterprise }\end{array}$ & Since 1920 & $\begin{array}{l}\text { Regional Sales } \\
\text { Manager }\end{array}$ \\
\hline Company N & $\begin{array}{l}\text { The company operates in the chemical industry } \\
\text { in several segments: coatings, adhesives, resins, } \\
\text { pigments, and other specialty chemicals. }\end{array}$ & $\begin{array}{l}\text { Micro-sized } \\
\text { enterprise }\end{array}$ & Missing answer & $\mathrm{CSO}$ \\
\hline Company $\mathrm{O}$ & $\begin{array}{l}\text { Provider of digital system solutions for } \\
\text { measurement methods in the paints and } \\
\text { coatings industry. }\end{array}$ & $\begin{array}{l}\text { Small-sized } \\
\text { enterprise }\end{array}$ & Since 2014 & Key Account Manager \\
\hline Company P & Missing answer. & $\begin{array}{l}\text { Large-sized } \\
\text { enterprise }\end{array}$ & Missing answer & Head of Sales \\
\hline
\end{tabular}


Table 3. Cont.

\begin{tabular}{|c|c|c|c|c|}
\hline Company & Area of Business & Size & $\begin{array}{l}\text { Years in the } \\
\text { Industry }\end{array}$ & Responding Person \\
\hline Company R & $\begin{array}{l}\text { Production of decorative coatings, } \\
\text { industrial paints for wood and metals, } \\
\text { car refinish program, road paints, } \\
\text { resins, powder coatings. }\end{array}$ & $\begin{array}{l}\text { Large-sized } \\
\text { enterprise }\end{array}$ & Since 1988 & $\begin{array}{l}\text { Assistant in the Sales } \\
\text { Department }\end{array}$ \\
\hline Company S & $\begin{array}{l}\text { Production and sales: paints and } \\
\text { coatings, chemicals. }\end{array}$ & $\begin{array}{l}\text { Large-sized } \\
\text { enterprise }\end{array}$ & Since 2007 & Sales Manager \\
\hline
\end{tabular}

Respondents initially answered some key questions about the company (company size, size of sales assortment, type of customers, etc.). Subsequently, the respondents answered questions about the sales channels. In particular, they estimated the percentage of sales of raw materials and finished products by individual sales channels (for B2B and B2C), ranked sales channels by the speed of order realization (from fastest to slowest), and assessed sales trends in sales channels. The survey questionnaire was prepared in several languages and with the help of the $1 \mathrm{ka}$ tool. The $1 \mathrm{ka}$ tool is a powerful, easy and safe survey tool that provides advanced support for all steps of the web survey process [45]. However, the online survey could not provide all the necessary information about the processes and other details. This was why we invited respondents to structured interviews.

Stage 3: The third step of the research was to execute a structured interview to obtain the information needed to prepare sales channel models. The questions were based on the requirements of business process modeling and indicators for analyzing structural and operational (time) efficiency of processes. The third stage also involved experts from the coatings industry (Figure 1).

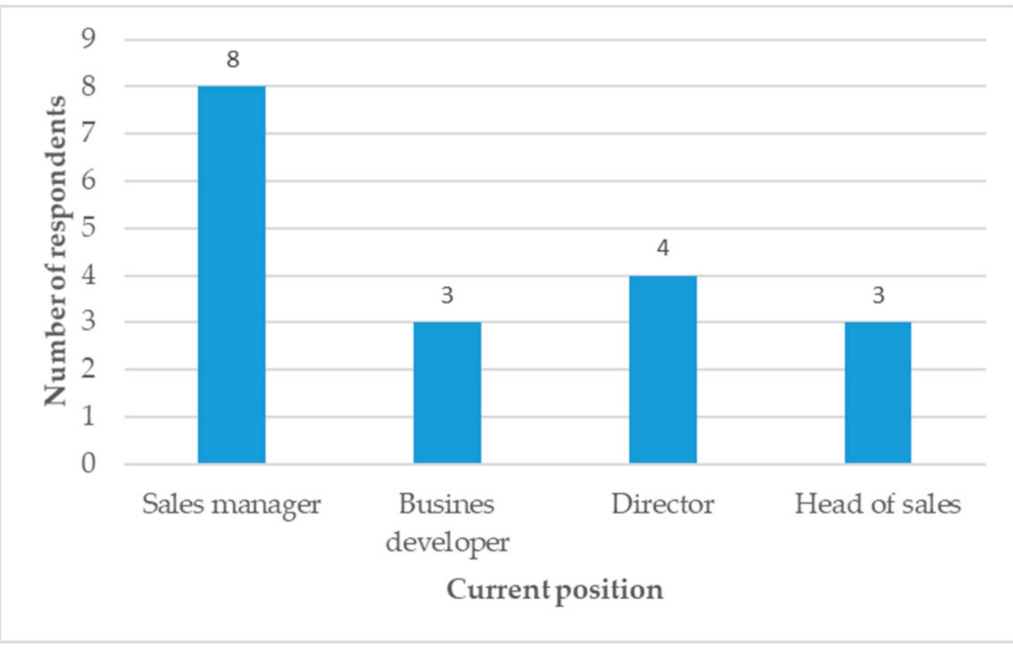

Figure 1. Current positions of the responding experts.

The interviews involved companies that sell through the three most common sales channels. The interviews were conducted face to face using MS Teams and focused on gathering detailed information on sales channel processes such as process activities, positions, documentation, process information support, etc. Based on the obtained data, process models were prepared. Given the need for detailed and accurate information on the execution of individual processes and the preparation of appropriate models, the interview was deemed to be the most appropriate for this research stage. The architecture of integrated information systems (ARIS) tool and methodology, more specifically the EPC model type, was used for modeling as it presented the user's perspective of the process [46-48]. Standard symbols [49] for business objects and relations were used. The process modeling methodology is described in detail by Kern et al. [1]. 
Stage 4: Structural and operational analysis were performed in the research. The first analysis was performed based on the structural indicators connected with business process structural complexity $[17,18,21,27]$. The second was performed based on the operational indicators connected with time, costs, and quality $[19,50]$. The paper presents the structural analysis and the time aspect of the operational analysis performed by the PERT method, also used and described by Kern et al. [1].

Stage 5: For significant progress in the sales process, it is necessary to use business process reengineering (BPR) and the digital transformation approach [51]. In addition to process analysis, this upgrade requires relevant and up-to-date data and a technical enabler $[52,53]$. An appropriate technical enabler for the digital transformation of the sales channel process is selected [5]. The tool is the only all-in-one tool that enables an online, real-time search for ingredients, the virtual development of product formulation, and the creation of digital technical and safety data sheets. Therefore, Allchemist is a common technical enabler as it is developed for developers, vendors, and suppliers. The user takes ingredients data from the structured database available in digital form and stored in the cloud. The user has free access to many ingredients and is thus guided by the platform to select only those that are functionally relevant, safe, environmentally acceptable, and affordable [1]. The digital sales channel was designed based on the selected technical enabler; consequently, the To-Be model was prepared. The distinction between the digital sales channel and online sales [54-56] was used in the manuscript to emphasize the result of digital transformation by introducing a common technical enabler. A digital sales channel is used by several companies in the logistics chain. This means that all companies use a common technical enabler, which is generally independent. Using an independent common technical enabler allows companies to access and edit data in a common database. Companies that can compete with each other must appear on the same platform, which improves the whole system's efficiency. An online sales channel, on the other hand, is generally established by one company (the one that sells), while other companies and individuals (those who buy) access the data and perform transactions.

Stage 6: In the last step, we checked the justification of the digital sales channel in terms of structural efficiency indicators and throughput time (operational efficiency indicator). We evaluated changes with structural efficiency indicators first. In this way, we quickly assessed their impact on the process execution, even before the implementation [27]. The time that transpires from placing the order to the receipt of products is one of the most important factors for the customer when deciding on the choice of supplier [32]; therefore, we also assessed the impact of the changes on the process throughput time. We used data on estimates of the execution times of each process phase, which were collected during structured interviews.

\section{Results}

\subsection{Sales Channels in the Coatings Industry}

With the help of a survey among the sellers of ingredients and products, the results of the research showed which sales channels were most often used. The volume of sales by individual sales channels varied according to the end customer type (B2C or B2B). In the sale of products to end customers (B2C), the largest percentage of sales was made through the following three sales channels:

- Personal sales;

- Retail;

- Online sales.

The percentage of sales by individual sales channels and individual product types in sales to end customers (B2C) is shown in Figure 2. 


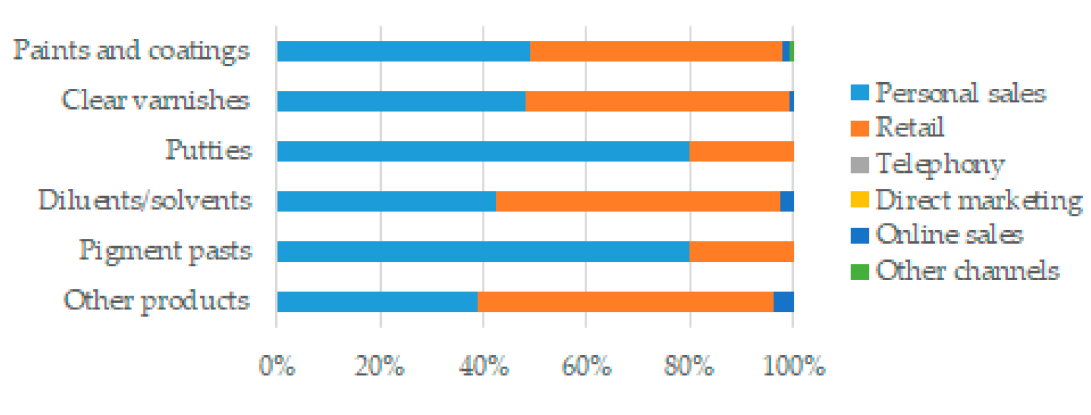

(a)

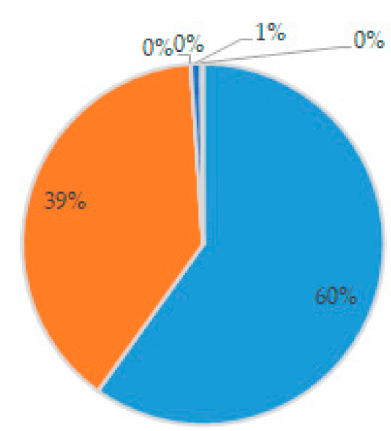

(b)

Figure 2. Sales of products to end customers (B2C): (a) Sales percentage of each product category by individual sales channel. (b) The total percentage of sales by individual sales channel.

In the sale of ingredients and products to other companies (B2B), the same three sales channels were also most often used, but the percentage of sales by individual sales channel, in this case, slightly changed (Figure 3). In this case, the sales channels followed each other in the following order in terms of sales volume:

- Personal sales;

- Online sales;

- Retail.

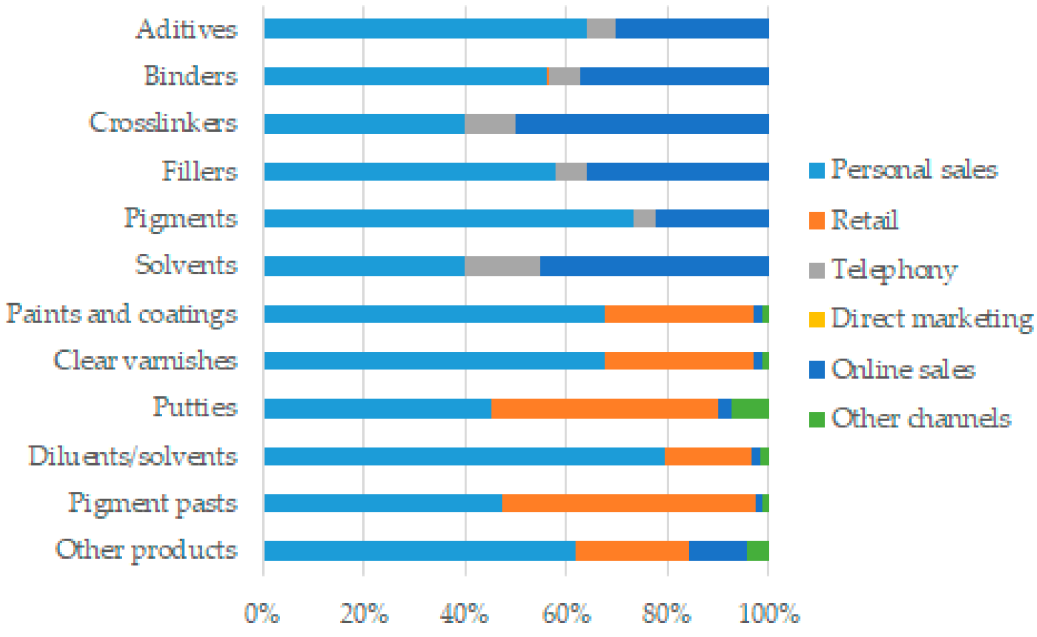

(a)

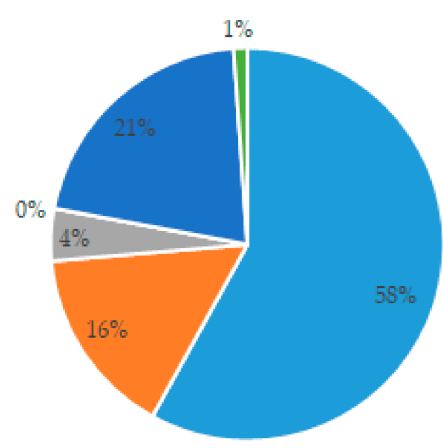

(b)

Figure 3. Sales of products to other companies (B2B): (a) Sales percentage of each product category by individual sales channel. (b) The total percentage of sales by individual sales channel.

The research also revealed that the volume of sales by individual sales channels was changing. The results showed that sales through the online sales channel increased the most, while sales through the telephone sales channel decreased (Figure 4). Personal and online sales channels were most commonly used for marketing purposes (Figure 5). 


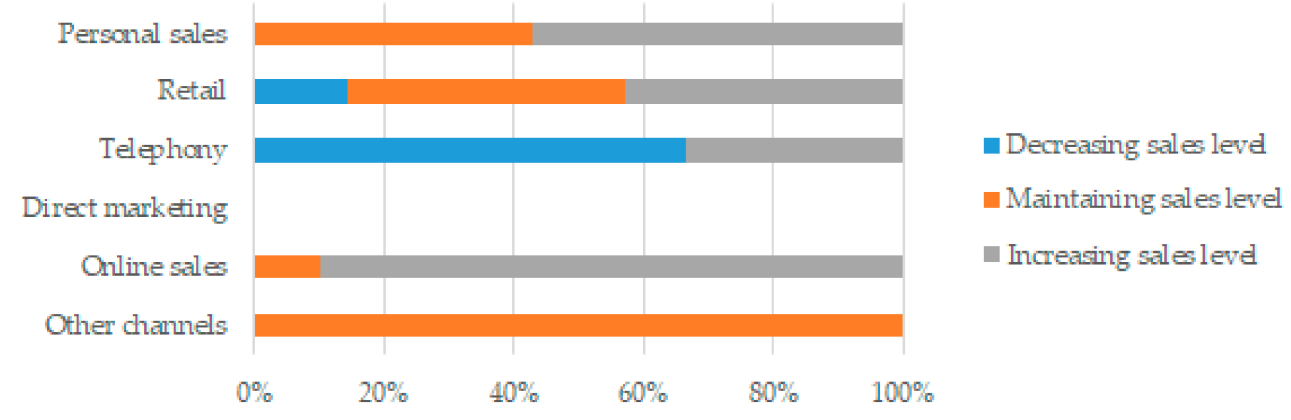

Figure 4. Sales trends by individual sales channels.

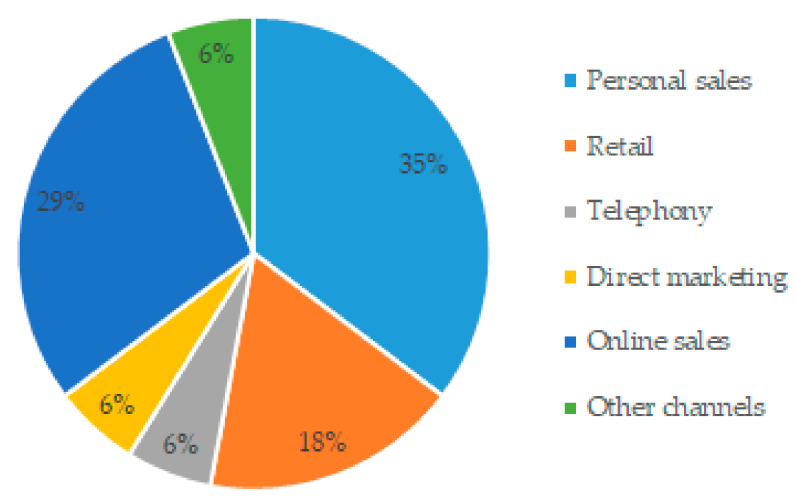

Figure 5. Use of individual sales channels for marketing.

Based on the survey results, the three most commonly used sales channels (personal sales, retail, and online sales) were included to continue the research, covering more than $95 \%$ of the sales volume (Figures 2 and 3 ).

\subsection{As-Is Sales Processes}

The research aim was to identify the possibilities and justification for the implementation of a digital sales channel. Therefore, we subsequently checked the involvement and execution of individual phases in the most frequently used sales channels through structured interviews. For this purpose, we designed detailed process models of three selected sales channels.

We found that sales processes differ in the number and sequence of activities, the involvement of various positions (departments or workplaces) in the process execution, in created physical or electronic documents, the number of decisions in the process, included information support, and the percentage of supported activities. However, we could identify the similarity of individual phases of the sales process for the same sales channel for all sellers, as shown in Table 4 and Figure 6. 
Table 4. Inclusion of sales process phases in sales channels.

\begin{tabular}{|c|c|c|c|c|}
\hline \multirow{2}{*}{ No. 1} & \multirow{2}{*}{ Phases of the Sales Process } & \multicolumn{3}{|c|}{ Sales Channels } \\
\hline & & Personal Sales & Retail & Online Sales \\
\hline 10 & Marketing effort including branding & $\sqrt{ }$ & $\sqrt{ }$ & $\sqrt{ }$ \\
\hline 20 & Customer selection/acquiring & $\sqrt{ }$ & & \\
\hline 30 & Additional information provided by the seller & $\sqrt{ }$ & $\sqrt{ }$ & $\sqrt{ }$ \\
\hline 40 & Billing and payment & & & $\sqrt{ }^{2}$ \\
\hline 50 & Product supply & $\sqrt{ }$ & & $\sqrt{ }$ \\
\hline 60 & Product storage & $\sqrt{ }$ & & $\sqrt{ }$ \\
\hline 70 & Inventory and store merchandising & & $\sqrt{ }$ & \\
\hline 80 & Picking and packing & $\sqrt{ }$ & $\sqrt{ }$ & $\sqrt{ }$ \\
\hline 90 & Distribution of products & $\sqrt{ }$ & & $\sqrt{ }$ \\
\hline 100 & Billing and payment & $\sqrt{ }$ & $\sqrt{ }$ & $\sqrt{ }$ \\
\hline
\end{tabular}

${ }^{1}$ The table lists the sales process phases identified during the design of detailed process models. Since only some of the listed phases are included in individual sales channels, we also marked them with the phase number to make it easier to track the inclusion of each phase in other tables. ${ }^{2}$ Within the online sales channel, the customer can decide to make a payment for the products during the order of products or after delivery.

\section{PERSONAL SALES}

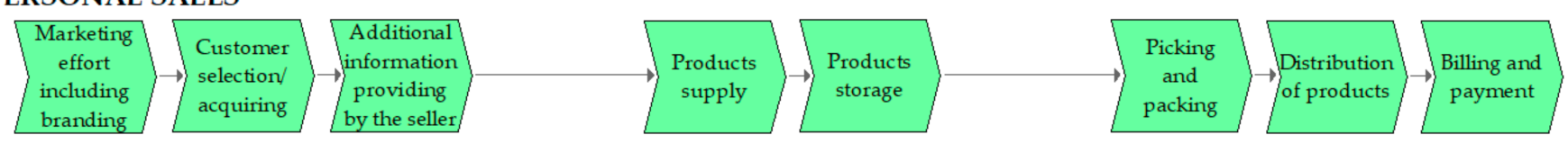

RETAIL

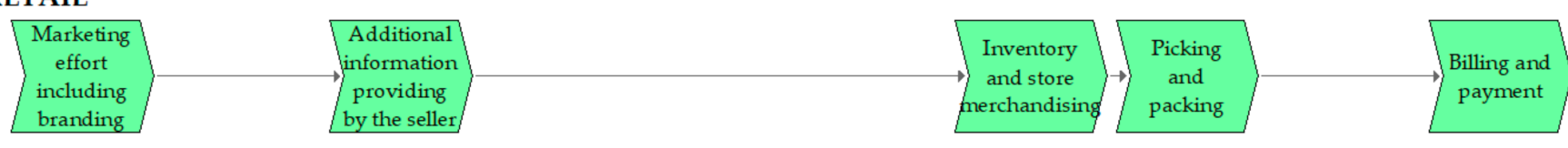

\section{ONLINE SALES}

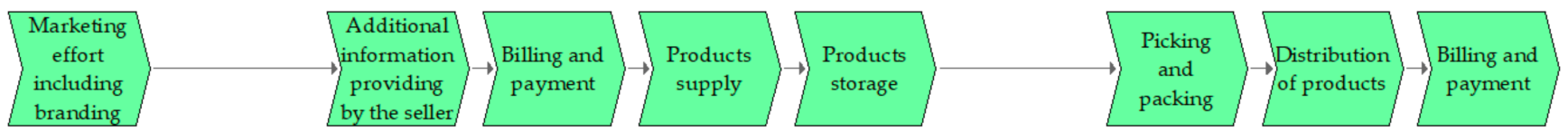

Figure 6. The sequence of sales process phase execution by sales channels.

\subsection{To-Be Process of a Digital Sales Channel}

The survey results showed that the percentage of sales through the online sales channel is increasing in the coatings industry, which is in line with the general trend of online sales. However, the increase in sales through this sales channel is lower than expected, given the increase in online sales in other industries. When conducting structured interviews, it was found out why this is the case in the coatings industry.

Customers more often decide to buy through an online sales channel when buying already well-known products. However, when they decide to make their first purchase, they need reliable and detailed product information. Manufacturers and sellers in the coatings industry are obligated to publish information on the product's properties, which are available in the safety data sheets or technical data sheets, usually in the form of PDF documents. Access to them is time-consuming, which deters potential buyers from making the purchase.

Based on these findings, we designed the To-Be digital sales channel. In the phase of providing the additional information, we included information support-a common technical enabler that allows customers to access all product information online. The phases' sequence of the sales process and the inclusion of a common technical enabler in the digital sales channel is shown in Figure 7. 


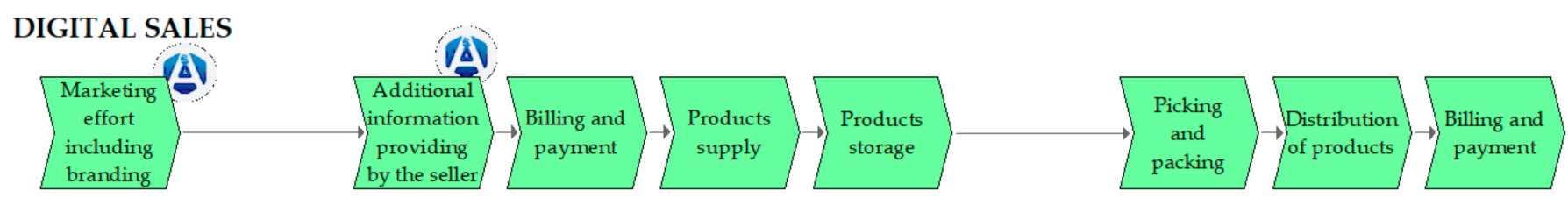

Figure 7. The sequence of phases and inclusion of a technical enabler in a digital sales channel.

In the verification stage, we excluded retail sales, as it is not used in practice when selling ingredients (Figure 3).

\subsection{Verification of Digital Sales Channel Advantages}

We assessed the advantages of the digital sales channel in comparison with the personal and online sales channels in the first step based on structural indicators. The process of evaluating the structural complexity of a business process is presented in detail in the article by Urh et al. [57]. First, Table 5 shows the data on the structural complexity of sales channel models.

Table 5. Data of the process's complexity.

\begin{tabular}{|c|c|c|c|}
\hline \multirow{2}{*}{ Process Complexity Data } & \multicolumn{3}{|c|}{ Sales Channels } \\
\hline & Personal Sales & Online Sales & Digital Sales \\
\hline The number of activities & 37 & 26 & 29 \\
\hline $\begin{array}{l}\text { The number of possible transitions } \\
\text { between activities }\end{array}$ & 30 & 20 & 21 \\
\hline The number of positions (employees) & 11 & 9 & 8 \\
\hline $\begin{array}{l}\text { The number of connections between } \\
\text { positions and activities }\end{array}$ & 43 & 26 & 33 \\
\hline The number of used documents & 9 & 9 & 5 \\
\hline $\begin{array}{l}\text { The number of documents created } \\
\text { within a process }\end{array}$ & 6 & 7 & 3 \\
\hline $\begin{array}{l}\text { The number of decisions made } \\
\text { by employees }\end{array}$ & 3 & 2 & 3 \\
\hline $\begin{array}{l}\text { The number of used information } \\
\text { technology (ICT) }\end{array}$ & 5 & 3 & 4 \\
\hline $\begin{array}{l}\text { The number of activities supported by } \\
\text { the information technology (ICT) }\end{array}$ & 18 & 14 & 16 \\
\hline
\end{tabular}

The table for the process complexity data (Table 5) shows that some data differ significantly between sales channels. For example, they differ in the number of activities, the number of transitions between activities, the number of connections between positions and activities, the number of used documents, and the number of documents created within a process. Based on the collected data, we assessed the models of sales channel processes according to the following structural indicators (Table 6) [20,23,57]. A rating scale from 1 to 100 was used in the evaluation, where 1 represents the worst score and 100 the best score for each indicator.

From the obtained results of the sales channel evaluation, we can see that most of the grades in the digital sales channel improved. However, as follows from the theory for estimating the complexity of business process models [58], this is a rough estimate that facilitates the decision to implement changes in practice. The evaluation of the actual impact of the digital sales channel implementation was therefore also performed based on the operational indicators from a time perspective. 
Table 6. Evaluation of sales channel processes according to structural indicators.

\begin{tabular}{lccc}
\hline \multirow{2}{*}{ Indicators of Process Structure } & \multicolumn{3}{c}{ Sales Channels } \\
\cline { 2 - 4 } & Personal Sales & Online Sales & Digital Sales \\
\hline Process activities & 97 & 96 & 97 \\
Number of transitions & 19 & 23 & 28 \\
between activities & 9 & 11 & 13 \\
Process positions & 11 & 11 & 14 \\
Level of inclusion of the positions & 33 & 22 & 40 \\
Percentage of created documents & 84 & 73 & 90 \\
Percentage of created documents & 92 & 92 & 90 \\
and activities & 80 & 67 & 75 \\
Process decisions & 49 & 54 & 55 \\
Process information technologies & & & \\
Percentage of activities supported by & & & \\
the ICT & &
\end{tabular}

To analyze the throughput time $[49,59,60]$ of the sales process by individual sales channel, data on the structure of individual phase times in the process were collected: waiting time, preparation-finishing time, and processing time. Table 7 presents the data for the personal sales channel, Table 8 for the online sales channel, and Table 9 for the digital sales channel.

Table 7. Time estimates of the personal sales channel's phases.

\begin{tabular}{|c|c|c|c|c|c|c|c|}
\hline No. & Process Phase & $\begin{array}{l}\text { Time Estimates } \\
\text { (in Hours, h) }\end{array}$ & Optimistic & $\begin{array}{c}\text { Most } \\
\text { Probable }\end{array}$ & Pessimistic & Expected & $\begin{array}{c}\text { Phase } \\
\text { Throughput }\end{array}$ \\
\hline \multirow{3}{*}{10} & \multirow{3}{*}{$\begin{array}{l}\text { Marketing effort, } \\
\text { including branding }\end{array}$} & Waiting & 2.00 & 4.00 & 8.00 & 4.33 & \multirow{3}{*}{$175.38^{1}$} \\
\hline & & Orientation & 0.30 & 1.00 & 2.00 & 1.05 & \\
\hline & & Processing & 80.00 & 160.00 & 300.00 & 170.00 & \\
\hline \multirow{3}{*}{20} & \multirow{3}{*}{$\begin{array}{c}\text { Customer } \\
\text { selection/acquisition }\end{array}$} & Waiting & 0.00 & 0.00 & 0.01 & 0.00 & \multirow{3}{*}{0.28} \\
\hline & & Orientation & 0.00 & 0.00 & 0.00 & 0.00 & \\
\hline & & Processing & 0.13 & 0.25 & 0.50 & 0.27 & \\
\hline \multirow{3}{*}{30} & \multirow{3}{*}{$\begin{array}{l}\text { Additional information } \\
\text { provided by the seller }\end{array}$} & Waiting & 0.02 & 0.04 & 0.10 & 0.05 & \multirow{3}{*}{0.61} \\
\hline & & Orientation & 0.02 & 0.04 & 0.10 & 0.05 & \\
\hline & & Processing & 0.10 & 0.50 & 1.00 & 0.52 & \\
\hline \multirow{3}{*}{50} & \multirow{3}{*}{ Product supply } & Waiting & 0.02 & 0.04 & 0.10 & 0.05 & \multirow{3}{*}{0.32} \\
\hline & & Orientation & 0.02 & 0.04 & 0.10 & 0.05 & \\
\hline & & Processing & 0.05 & 0.20 & 0.50 & 0.23 & \\
\hline \multirow{3}{*}{60} & \multirow{3}{*}{ Product storage } & Waiting & 0.02 & 0.04 & 0.10 & 0.05 & \multirow{3}{*}{1.61} \\
\hline & & Orientation & 0.30 & 1.00 & 2.00 & 1.05 & \\
\hline & & Processing & 0.10 & 0.50 & 1.00 & 0.52 & \\
\hline \multirow{3}{*}{80} & \multirow{3}{*}{ Picking and packing } & Waiting & 0.02 & 0.04 & 0.10 & 0.05 & \multirow{3}{*}{0.61} \\
\hline & & Orientation & 0.02 & 0.04 & 0.10 & 0.05 & \\
\hline & & Processing & 0.10 & 0.50 & 1.00 & 0.52 & \\
\hline \multirow{3}{*}{90} & \multirow{3}{*}{ Distribution of products } & Waiting & 0.00 & 0.00 & 0.00 & 0.00 & \multirow{3}{*}{$0.00^{2}$} \\
\hline & & Orientation & 0.00 & 0.00 & 0.00 & 0.00 & \\
\hline & & Processing & 0.00 & 0.00 & 0.00 & 0.00 & \\
\hline \multirow{3}{*}{100} & \multirow{3}{*}{ Billing and payment } & Waiting & 0.02 & 0.04 & 0.10 & 0.05 & \multirow{3}{*}{0.32} \\
\hline & & Orientation & 0.02 & 0.04 & 0.10 & 0.05 & \\
\hline & & Processing & 0.05 & 0.20 & 0.50 & 0.23 & \\
\hline
\end{tabular}

${ }^{1}$ Estimated phase times are given for the sale of a product that is executed once regardless of how many sales have been executed with the product. The number of completed sales varies between products, so it does not make sense to calculate the average time spent per sale for this phase. Therefore, this phase was excluded from the calculation of the process throughput time. ${ }^{2}$ It was impossible to obtain a time estimate from the seller because, in most companies, the delivery of products to the consumer is executed by external contractors (delivery service, express mail, etc.). Therefore, this time could not be taken into account for any sales channel. 
Table 8. Time estimates of the online sales channel's phases.

\begin{tabular}{|c|c|c|c|c|c|c|c|}
\hline No. & Process Phase & $\begin{array}{l}\text { Time Estimates } \\
\text { (in Hours, h) }\end{array}$ & Optimistic & $\begin{array}{c}\text { Most } \\
\text { Probable }\end{array}$ & Pessimistic & Expected & $\begin{array}{c}\text { Phase } \\
\text { Throughput }\end{array}$ \\
\hline \multirow{3}{*}{10} & \multirow{3}{*}{$\begin{array}{l}\text { Marketing effort, } \\
\text { including branding }\end{array}$} & Waiting & 2.00 & 4.00 & 8.00 & 4.33 & \multirow{3}{*}{$175.38^{1}$} \\
\hline & & Orientation & 0.30 & 1.00 & 2.00 & 1.05 & \\
\hline & & Processing & 80.00 & 160.00 & 300.00 & 170.00 & \\
\hline \multirow{3}{*}{30} & \multirow{3}{*}{$\begin{array}{l}\text { Additional information } \\
\text { provided by the seller }\end{array}$} & Waiting & 0.02 & 0.04 & 0.10 & 0.05 & \multirow{3}{*}{0.61} \\
\hline & & Orientation & 0.02 & 0.04 & 0.10 & 0.05 & \\
\hline & & Processing & 0.10 & 0.50 & 1.00 & 0.52 & \\
\hline \multirow{3}{*}{40} & \multirow{3}{*}{ Billing and payment } & Waiting & 0.00 & 0.00 & 0.00 & 0.00 & \multirow{3}{*}{$0.00^{3}$} \\
\hline & & Orientation & 0.00 & 0.00 & 0.00 & 0.00 & \\
\hline & & Processing & 0.00 & 0.00 & 0.00 & 0.00 & \\
\hline \multirow{3}{*}{50} & \multirow{3}{*}{ Product supply } & Waiting & 0.02 & 0.04 & 0.10 & 0.05 & \multirow{3}{*}{0.32} \\
\hline & & Orientation & 0.02 & 0.04 & 0.10 & 0.05 & \\
\hline & & Processing & 0.05 & 0.20 & 0.50 & 0.23 & \\
\hline \multirow{3}{*}{60} & \multirow{3}{*}{ Product storage } & Waiting & 0.02 & 0.04 & 0.10 & 0.05 & \multirow{3}{*}{1.61} \\
\hline & & Orientation & 0.30 & 1.00 & 2.00 & 1.05 & \\
\hline & & Processing & 0.10 & 0.50 & 1.00 & 0.52 & \\
\hline \multirow{3}{*}{80} & \multirow{3}{*}{ Picking and packing } & Waiting & 0.02 & 0.04 & 0.10 & 0.05 & \multirow{3}{*}{0.61} \\
\hline & & Orientation & 0.02 & 0.04 & 0.10 & 0.05 & \\
\hline & & Processing & 0.10 & 0.50 & 1.00 & 0.52 & \\
\hline \multirow{3}{*}{90} & \multirow{3}{*}{ Distribution of products } & Waiting & 0.00 & 0.00 & 0.00 & 0.00 & \multirow{3}{*}{$0.00^{2}$} \\
\hline & & Orientation & 0.00 & 0.00 & 0.00 & 0.00 & \\
\hline & & Processing & 0.00 & 0.00 & 0.00 & 0.00 & \\
\hline \multirow{3}{*}{100} & \multirow{3}{*}{ Billing and payment } & Waiting & 0.00 & 0.00 & 0.00 & 0.00 & \multirow{3}{*}{$0.00^{3}$} \\
\hline & & Orientation & 0.00 & 0.00 & 0.00 & 0.00 & \\
\hline & & Processing & 0.00 & 0.00 & 0.00 & 0.00 & \\
\hline
\end{tabular}

${ }^{1,2}$ The same notes as for Table $7 .{ }^{3}$ The "Billing and payment" phase is divided into two parts. Since the buyer chooses a payment method and pays, the time estimate by the seller is not relevant. Therefore, this time could not be taken into account for the online and digital sales channels.

Table 9. Time estimates of the digital sales channel' phases.

\begin{tabular}{|c|c|c|c|c|c|c|c|}
\hline No. & Process Phase & $\begin{array}{l}\text { Time Estimates } \\
\text { (in Hours, h) }\end{array}$ & Optimistic & $\begin{array}{c}\text { Most } \\
\text { Probable }\end{array}$ & Pessimistic & Expected & $\begin{array}{c}\text { Phase } \\
\text { Throughput }\end{array}$ \\
\hline \multirow{3}{*}{10} & \multirow{3}{*}{$\begin{array}{l}\text { Marketing effort, } \\
\text { including branding }\end{array}$} & Waiting & 2.00 & 4.00 & 8.00 & 4.33 & \multirow{3}{*}{$175.38^{1}$} \\
\hline & & Orientation & 0.30 & 1.00 & 2.00 & 1.05 & \\
\hline & & Processing & 80.00 & 160.00 & 300.00 & 170.00 & \\
\hline \multirow{3}{*}{30} & \multirow{3}{*}{$\begin{array}{l}\text { Additional information } \\
\text { provided by the seller }\end{array}$} & Waiting & 0.00 & 0.00 & 0.00 & 0.00 & \multirow{3}{*}{$0.00^{4}$} \\
\hline & & Orientation & 0.00 & 0.00 & 0.00 & 0.00 & \\
\hline & & Processing & 0.00 & 0.00 & 0.00 & 0.00 & \\
\hline \multirow{3}{*}{40} & \multirow{3}{*}{ Billing and payment } & Waiting & 0.00 & 0.00 & 0.00 & 0.00 & \multirow{3}{*}{$0.00^{3}$} \\
\hline & & Orientation & 0.00 & 0.00 & 0.00 & 0.00 & \\
\hline & & Processing & 0.00 & 0.00 & 0.00 & 0.00 & \\
\hline \multirow{3}{*}{50} & \multirow{3}{*}{ Product supply } & Waiting & 0.02 & 0.04 & 0.10 & 0.05 & \multirow{3}{*}{0.32} \\
\hline & & Orientation & 0.02 & 0.04 & 0.10 & 0.05 & \\
\hline & & Processing & 0.05 & 0.20 & 0.50 & 0.23 & \\
\hline \multirow{3}{*}{60} & \multirow{3}{*}{ Product storage } & Waiting & 0.02 & 0.04 & 0.10 & 0.05 & \multirow{3}{*}{1.61} \\
\hline & & Orientation & 0.30 & 1.00 & 2.00 & 1.05 & \\
\hline & & Processing & 0.10 & 0.50 & 1.00 & 0.52 & \\
\hline \multirow{3}{*}{80} & \multirow{3}{*}{ Picking and packing } & Waiting & 0.02 & 0.04 & 0.10 & 0.05 & \multirow{3}{*}{0.61} \\
\hline & & Orientation & 0.02 & 0.04 & 0.10 & 0.05 & \\
\hline & & Processing & 0.10 & 0.50 & 1.00 & 0.52 & \\
\hline \multirow{3}{*}{90} & \multirow{3}{*}{ Distribution of products } & Waiting & 0.00 & 0.00 & 0.00 & 0.00 & \multirow{3}{*}{$0.00^{2}$} \\
\hline & & Orientation & 0.00 & 0.00 & 0.00 & 0.00 & \\
\hline & & Processing & 0.00 & 0.00 & 0.00 & 0.00 & \\
\hline \multirow{3}{*}{100} & \multirow{3}{*}{ Billing and payment } & Waiting & 0.00 & 0.00 & 0.00 & 0.00 & \multirow{3}{*}{$0.00^{3}$} \\
\hline & & Orientation & 0.00 & 0.00 & 0.00 & 0.00 & \\
\hline & & Processing & 0.00 & 0.00 & 0.00 & 0.00 & \\
\hline
\end{tabular}

1,2 The same notes as for Table $7 .{ }^{3}$ The same notes as for Table $8 .{ }^{4}$ The execution of the phase "Additional information provided by the seller" is left to the buyer (the necessary information is accessible to the buyer with the help of a common technical enabler). Therefore, the time estimate by the seller is not relevant and could not be taken into account. 
The tables of time estimates for the execution of individual phases show that the phase throughput times do not change between sales channels. However, the phases included in the process execution changes between sales channels, or the execution of an individual phase can be left to the customer. In this way, the difference in the required time to process throughput appears on the seller's side.

Based on the estimated times for the execution of each phase of the sales channels (Tables 7-9), the difference in the time required to execute individual sales (Table 10) with regard to personal sales is shown below.

Table 10. Process throughput time of the sales channels.

\begin{tabular}{|c|c|c|c|c|}
\hline \multirow{2}{*}{ No. } & \multirow{2}{*}{ Phases of the Sales Process } & \multicolumn{3}{|c|}{ Phase Throughput Time (h) } \\
\hline & & Personal Sales & Online Sales & Digital Sales \\
\hline 10 & Marketing effort, including branding & $175.38^{1}$ & $175.38^{1}$ & $175.38^{1}$ \\
\hline 20 & Customer selection/acquisition & 2.28 & $0.00^{2}$ & $0.00^{2}$ \\
\hline 30 & Additional information provided by the seller & 0.61 & 0.61 & $0.00^{3}$ \\
\hline 40 & Billing and payment & $0.00^{2}$ & $0.00^{3}$ & $0.00^{3}$ \\
\hline 50 & Product supply & 0.32 & 0.32 & 0.32 \\
\hline 60 & Product storage & 1.61 & 1.61 & 1.61 \\
\hline 80 & Picking and packing & 0.61 & 0.61 & 0.61 \\
\hline 90 & Distribution of products & $0.00^{4}$ & $0.00^{4}$ & $0.00^{4}$ \\
\hline \multirow[t]{3}{*}{100} & Billing and payment & 0.32 & $0.00^{3}$ & $0.00^{3}$ \\
\hline & PROCESS THROUGHPUT TIME: & 3.75 & 3.15 & 2.54 \\
\hline & THROUGHPUT TIME REDUCTION (in \%): & & $15.9 \%$ & $32.1 \%$ \\
\hline
\end{tabular}

1 The phase time was obtained per product and not per sales repetition (Tables 7-9), so it was not taken into account in the further calculation. ${ }^{2}$ The phase of the sales process is not included in the sales channel. ${ }^{3}$ The phase of the sales process is executed automatically or by the customer. ${ }^{4}$ External contractors carry out delivery of products to the consumer (delivery service, express mail, etc.). Therefore, time is not included in the process throughput time.

The obtained results (Table 10) show that the time required to carry out one repetition of the sales process through the online sales channel is $15.9 \%$ shorter than that in personal sales. However, this form of sales is not as common as sellers would like. If the buyer is not familiar with the product, he does not get all the necessary information about the product and must inquire about it personally with the seller. In this case, the advantage of the digital sales channel is emphasized. This channel is $32.1 \%$ faster than the personal sales channel and $16.3 \%$ faster than the online sales channel. At the same time, the channel provides the customer insight into all data on product composition and properties.

However, it is necessary to consider that in establishing a digital sales channel, the seller or manufacturer (its development engineer) must invest some additional effort in entering the data of an individual product into a common technical enabler that would facilitate this form of the sales channel. In an experiment presented in a study by Kern et al. [3], it was shown that a user needs to complete an average of $6 \mathrm{~h}$ of training to work with a common technical enabler [5]. Such a trained user (development engineer) needs about $32 \mathrm{~min}(32.03 \pm 7.14 \mathrm{~min})$ to enter the ingredient data and about $12 \mathrm{~min}(11.96 \pm 5.49 \mathrm{~min})$ to enter the product data (formulations).

Given the savings shown in Table 10, we see that the effort (6 h) made to train an individual user in terms of personal sales is compensated with five sales through the digital channel and with ten through online sales. Assuming that the average product consists of seven components, it would be necessary to devote less than $4 \mathrm{~h}$ to data entry, compensated with four or seven sales via the digital channel. If the data entry of the product to the common technical enabler were performed with a partially automatic transfer (data parsing), it would take less than 25 min to transfer the average product. The calculation considers that data parsing requires $10 \mathrm{~s}$ and an additional $10 \%$ of manual entry time to check the correctness of data transfer. As a result, the company would be compensated with the first sale through the digital channel. 


\section{Discussion and Conclusions}

This study undoubtedly answered the research questions. The survey results showed that three sales channels are used the most in the coatings industry. We did not find a significant difference between companies that sell ingredients and companies that sell coatings or other end products. However, there are significant differences between end-user sales (B2C) and business sales (B2B). In both cases, three sales channels are predominant: personal sales (by sales representative), retail, and online sales. The online sales channel is growing the fastest of all sales channels. At the same time, the online sales channel is mainly used for marketing.

The survey, particularly the responses to structured interviews, show that there are limitations in the industry that prevent online sales from increasing its share as quickly as in other industries. The restrictions stem in particular from the specifics of the coatings industry in the field of ingredients. The specificity is that the ingredients are first offered to the developers (formulators). For instance, when developers develop coating, and if they use the offered ingredient in the coating, the sale of ingredients for production will then become routine (simple orders of known ingredients for a known customer). Ingredient retailers, therefore, distinguish sales processes between those addressed to formulators developing new coatings and those addressed to companies producing already developed coatings. In the research, we focused mainly on addressing the developers' sales process.

In previous studies [1-3], we found that developers use a limited set of ingredients to develop a new formulation. This is because access to available ingredients is limited. They still obtain data mainly from their databases (which are usually not up-to-date), safety and technical data sheets (mostly in PDF format, which is extremely time-consuming), or the sales databases of individual retailers to which they are linked. These databases are partial and do not offer an overview of different manufacturers and choices. Hence, formulators develop on a limited sample of ingredients, and the likelihood of an optimal formulation being developed is relatively small.

There is a common technical enabler [5] that allows product development in the coatings industry using an unlimited number of ingredients and available properties, in a way that shortens development time by $48 \%$ [1]; it is correspondingly cheaper [3] and more environmentally friendly [2]. However, this requires information on the ingredients. Research has shown several options for a common technical enabler to be filled and updated with this data. The formulator can enter ingredient data during the development process of the new coating. It compensates, but it is the most time-consuming option. The experiment showed that this takes up to $32 \mathrm{~min}$ on average for one ingredient. Another option is to parse the data from the PDF safety data sheets. This is a promising option as it shortens data entry time by more than $85 \%$. In any case, this technology will be used mainly to digitize data that is still in analog form. However, the only right way is to enter ingredient data directly from ingredient vendors. Only they have up-to-date data. Only they have the option to enter the data from the source and must therefore enter it only once. A fundamental argument is that vendors have the most significant interest in providing information about their ingredients to developers as soon and as cheaply as possible.

But there is also doubt as to whether it is worthwhile for manufacturers and retailers of ingredients to make an additional effort in using a digital sales channel with the common technical enabler in addition to established sales channels.

The first argument is that this gives them additional work, but at the same time, they do not know whether this channel would be effective and whether it would be successful. We completely dispelled these two doubts in this study. We have proven that the sales process in which we use the common digital enabler is shortened by more than $15 \%$ compared to the online sales channel, and by more than $32 \%$ compared to the personal sales channel. At the same time, we calculated that the input would be compensated by up to seven successful sales of ingredients or coatings. If parsing were implemented, we estimate that the input of the average product would be shortened by more than $210 \mathrm{~min}$. 
An additional argument against implementing the digital sales channel is that new information support needs to be employed. During research, we proved that this is not the case. We used a stand-alone, cloud-based common technical enabler for all calculations in the research. The company has no implementation costs, and training takes $6 \mathrm{~h}$ per user. This effort pays off after less than ten sales through the digital channel. However, it is a fact that with greater use of the new sales channel, there will be a need to automate data entry for ingredients to the common technical enabler. It will then be necessary to implement software interfaces, but the company could decide on this step only once their initial investments have been remunerated.

The final argument against implementing a digital sales channel is that it will "disclose its ingredients to competitors". This argument does not hold up. Detailed data of ingredient properties are already available via technical data sheets and safety data sheets in the coatings industry. If the competition wants to access this data, it can do so. However, the problem with "hiding" information is that they are more difficult to access for developers because they do not have time to search for a larger number of "competing" ingredients and therefore include only those already known and available in the new formulation. Accordingly, salespersons often fear that they will become redundant if all the data is available in one place. So far, this argument has proven to be the biggest obstacle to implementing improvements in all industries that have already digitalized (automotive, electronics, travel industry, etc.). At the same time, it is the most dangerous for companies. In all industries, rule breakers sooner or later take advantage of new technologies and use them to improve their processes. Undoubtedly, breakthrough companies in the coatings industry will also decide to implement a new digital sales channel. Those companies that will not use the digital sales channel will find it challenging to keep up with the breakthroughs. The tourism industry example shows that whoever did not use one of the common technical enablers early enough (e.g., Booking.com, Airbnb, etc.) found it extremely difficult to catch up. We can expect ingredient vendors to soon change from "ingredient data senders" to "developer consultants". This is a process that we will undoubtedly witness in the coatings industry in the near future.

The research indicated another important fact in a broader context. Digital transformation with the common technical enabler is most positively reflected when observing the entire coatings industry's logistics chain. The information on ingredients entered by ingredient vendors shortens the process, reduces its cost, and improves sales. Up-to-date data available at all times shortens, cheapens and improves the coating development process [1-3]. Most striking, however, is that product sales (B2B and B2C) can also be significantly improved because formulation specifications would have already been collected as safety data sheets, and technical data sheets, with various labels available at all times. If the logistics chain has several stages, the positive effects will be potentiated.

Our further research will be focused on the analysis of the advantages of using a common technical enabler and the digital sales channel for the entire logistics chain in the coatings industry.

Author Contributions: Conceptualization, E.K.A. and T.K.; methodology, E.K.A., B.U., and T.K.; software, E.K.A. and B.U.; validation, T.K.; formal analysis, E.K.A. and B.U.; investigation, E.K.A., M.S., and B.U.; resources, T.K.; data curation, E.K.A., M.S., and B.U.; writing-original draft preparation, E.K.A., B.U., and T.K.; writing-review and editing, E.K.A., B.U., M.S., and T.K.; visualization, B.U.; supervision, T.K.; project administration, T.K. All authors have read and agreed to the published version of the manuscript.

Funding: This research was supported by the Slovenian Research Agency: Program No. P5-0018—Decision Support Systems in Digital Business in the sum of EUR 1500.

Acknowledgments: The authors are grateful to the Laboratory of Enterprise Engineering, Faculty of Organizational Sciences, the University of Maribor for supporting the project.

Conflicts of Interest: The authors declare no conflict of interest. 


\section{References}

1. Kern, T.; Krhač, E.; Senegačnik, M.; Urh, B. Digitalizing the Paints and Coatings Development Process. Processes $2019,7,539-561$. [CrossRef]

2. Urh, B.; Senegačnik, M.; Kern, T.; Krhač, E. Reducing waste of laboratory tests in the coating development process. Pol. J. Environ. Stud. 2020, 29, 3841-3851. [CrossRef]

3. Kern, T.; Krhač Andrašec, E.; Urh, B.; Senegačnik, M. Digital transformation reduces costs of the paints and coatings development process. Coatings 2020, 10, 1-15. [CrossRef]

4. Dumas, M.; La Rosa, M.; Mendling, J.; Reijers, H.A. Fundamentals of Business Process Management, 2nd ed.; Springer: Berlin/Heidelberg, Germany, 2018; p. 2.

5. ALLCHEMIST®. Digital Platform for Experts Working in the Paint Coatings Industry Who Want to Work Directly with Data Instead of Datasheets 2018. Available online: https:/ / www.allchemist.net/ (accessed on 28 March 2021).

6. Bai, C.; Sarkis, J. A grey-based DEMATEL model for evaluating business process management critical success factors. Int. J. Prod. Econ. 2013, 146, 281-292. [CrossRef]

7. Guha, S.; Kettinger, W.J.; Teng, J.T.C. Business process reengineering: Building a Comprehensive Methodology. Inf. Syst. Manag. 1993, 10, 13-22. [CrossRef]

8. Trkman, P. The critical success factors of business process management. Int. J. Inf. Manag. 2010, 30, 125-134. [CrossRef]

9. Hilbert, M.; Cerrato, J. Utilize Digital Adoption Solutions to Assist with Process Transformation and Employee Experience-ID G00738480 [Gartner, Inc.]. Published 11 December 2020. Available online: www.gartner.com (accessed on 12 March 2021).

10. Andersson, B.; Bider, I.; Johannesson, P.; Perjons, E. Towards a formal definition of goal-oriented business process patterns. Bus. Process Manag. J. 2005, 11, 650-662. [CrossRef]

11. Aguilar, E.R.; Garcia, F.; Ruiz, F.; Piattini, M.; Visaggio, C.A.; Canfora, G. Evaluation of BPMN Models Quality-A Family of Experiments. In ENASE 2008, Proceedings of the 3rd International Conference on Evaluation of Novel Approaches to Software Engineering, Funchal, Madeira, Portugal, 4-7 May 2008; Gonzalez-Perez, C., Jablonski, S., Eds.; INSTICC: Madeira, Portugal, 2008 ; pp. 56-63.

12. Succi, G.; Predonzani, P.; Vernazza, T. Business Process Modeling with Objects, Costs and Human Resources. In Systems Modeling for Business Process Improvement; Bustard, D., Kawalek, P., Norris, M., Eds.; Artech House: Boston, MA, USA; London, UK, 2000; pp. $47-60$.

13. Likar, B.; Trček, D. Orde ab Chao Method for Disruptive Innovations Creation (With COVID-19 Pandemic Case Application). Front. Psychol. 2021, 11, 581968. [CrossRef]

14. Reijers, H.A.; Mendling, J. A study into the factors that influence the understandability of business process models. IEEE Trans. Syst. Man Cybern. Part A Syst. Hum. 2011, 41, 449-462. [CrossRef]

15. Mendling, J. Managing Structural and Textual Quality of Business Process Models. In Data-Driven Process Discovery and Analysis; Springer: Berlin/Heidelberg, Germany, 2013; pp. 100-111.

16. Vanderfeesten, I.; Cardoso, J.; Mendling, J.; Reijers, H.A.; van der Aalst, W. Quality Metrics for Business Process Models. In 2007 BPM and Workflow Handbook, 1st ed.; Fischer, L., Ed.; Future Strategies Inc.: Lighthouse Point, FL, USA, 2007; Volume 144, pp. $179-190$.

17. Cardoso, J. Business Process Control-Flow Complexity: Metric, Evaluation and Validation. Int. J. Web Serv. Res. 2008, 5, 49-76. [CrossRef]

18. Rolón, E.; Ruiz, F.; Garcia, F.; Piattini, M. Applying Software Metrics to evaluate Business Process Models. CLEI Electron. J. 2006, 9. [CrossRef]

19. van der Aalst, W.M.P. Business process management: A comprehensive survey. ISRN Softw. Eng. 2013, 2013, 1-37. [CrossRef]

20. Urh, B. Predicting the Effectiveness of a Business System from the Point of View of Managing Business Process Efficiency. Ph.D. Thesis, University of Maribor, Maribor, Slovenia, 2011.

21. Mendling, J.; Moser, M.; Neumann, G.; Verbeek, H.M.W.; Van Dongen, B.F.; van der Aalst, W.M.P. A Quantitative Analysis of Faulty EPCs in the SAP Reference Model; BPM Center Report BPM-06-08; BPM Center: Eindhoven, The Netherlands, 2006.

22. Sarnikar, S.; Deokar, A.V. A design approach for process-based knowledge management systems. J. Knowl. Manag. 2017, 21, 693-717. [CrossRef]

23. Urh, B.; Kokalj, S.; Zajec, M. The Importance of Structural Indicators in Assessing the Efficiency of Business Process Performance. In People and Sustainable Organization; Kern, T., Rajkovic, V., Eds.; Peter Lang GmbH: Frankfurt am Main, Germany, 2011; pp. 248-270.

24. Cardoso, J. Complexity analysis of BPEL web processes. Softw. Process Improv. Pract. 2007, 12, 35-49. [CrossRef]

25. Mendling, J.; Sánchez-González, L.; García, F.; La Rosa, M. Thresholds for error probability measures of business process models. J. Syst. Softw. 2012, 85, 1188-1197. [CrossRef]

26. Figl, K. Comprehension of procedural visual business process models. Bus. Inf. Syst. Eng. 2017, 59, 41-67. [CrossRef]

27. Cardoso, J.; Mendling, J.; Neumann, G.; Reijers, H.A. A Discourse on Complexity of Process Models. In Business Process Management Workshops, Proceedings of the International Conference on Business Process Management, Vienna, Austria, 4-7 September 2006; Eder, J., Dustdar, S., Eds.; Springer: Berlin/Heidelberg, Germany, 2006; pp. 117-128.

28. Gruhn, V.; Laue, R. Adopting the cognitive complexity measure for business process models. In Cognitive Informatics, Proceedings of the 2006 5th IEEE International Conference on Cognitive Informatics, Beijing, China, 17-19 July 2006; Yao, Y., Shi, Z., Wang, Y., Kinsner, W., Eds.; IEEE: New York, NY, USA, 2006; pp. 236-241. 
29. Irani, Z.; Hlupic, V.; Giaglis, G.M. Business process reengineering: An analysis perspective. Int. J. Flex. Manuf. Syst. 2002, 14, 5-10. [CrossRef]

30. Meglič, J.; Kern, T.; Urh, B.; Balkovec, J.; Roblek, M. Influence of Polyvalence Professionals on Product Development Process Efficiency. Strojarstvo 2009, 51, 105-121.

31. Alba, J.; Lynch, J.; Weitz, B.; Janiszewski, C.; Lutz, R.; Sawyer, A.; Wood, S. Interactive home shopping: Consumer, retailer, and manufacturer incentives to participate in electronic marketplaces. J. Mark. 1997, 61, 38-53. [CrossRef]

32. Payne, A.; Frow, P. The role of multichannel integration in customer relationship management. Ind. Mark. Manag. 2004, 33, 527-538. [CrossRef]

33. Neslin, S.A.; Grewal, D.; Leghorn, R.; Shankar, V.; Teerling, M.L.; Thomas, J.S.; Verhoef, P.C. Challenges and opportunities in multichannel customer management. J. Serv. Res. 2006, 9, 95-112. [CrossRef]

34. Neslin, S.A.; Shankar, V. Key issues in multichannel customer management: Current knowledge and future directions. J. Interact. Mark. 2009, 23, 70-81. [CrossRef]

35. Avery, J.; Steenburgh, T.J.; Deighton, J.; Caravella, M. Adding bricks to clicks: Predicting the patterns of cross-channel elasticities over time. J. Mark. 2012, 76, 96-111. [CrossRef]

36. Verhoef, P.C.; Kannan, P.K.; Inman, J.J. From multi-channel retailing to omni-channel retailing: Introduction to the special issue on multi-channel retailing. J. Retail. 2015, 91, 174-181. [CrossRef]

37. Kannan, P.K.; Reinartz, W.; Verhoef, P.C. The path to purchase and attribution modeling: Introduction to special section. Int. J. Res. Mark. 2016, 33, 449-456. [CrossRef]

38. Kannan, P.K. Digital marketing: A framework, review and research agenda. Int. J. Res. Mark. 2017, 34, 22-45. [CrossRef]

39. Van Heerde, H.J.; Dinner, I.; Neslin, S.A. Engaging the unengaged customer: The value of a retailer mobile up. Int. J. Res. Mark. 2019, 36, 420-438. [CrossRef]

40. Liu, H.; Lobschat, L.; Verhoef, P.C. Multichannel retailing: A review and research agenda. Found. Trends Mark. 2018, 12, 1-79. [CrossRef]

41. Liu, H.; Lobschat, L.; Verhoef, P.C.; Zhao, H. App adoption: The effect on purchasing of customers who have used a mobile website previously. J. Interact. Mark. 2019, 47, 16-34. [CrossRef]

42. Nibusiness Info.co.uk. The Sales Process. Available online: https://www.nibusinessinfo.co.uk/content/sales-process (accessed on 26 March 2021).

43. Burt, S.; Sparks, L. E-commerce and the retail process: A review. J. Retail. Consum. Serv. 2003, 10, 275-286. [CrossRef]

44. Melacini, M.; Tappia, E. A critical comparison of alternative distribution configurations in Omni-channel retailing in terms of cost and greenhouse gas emissions. Sustainability 2018, 10, 1-15. [CrossRef]

45. 1ka Enklik Anketa. Orodje za Anketiranje (Survey Tool). Available online: https://www.1ka.si/ (accessed on 27 March 2021).

46. Scheer, A.W. ARIS_Business Process: Framework, 2nd ed.; Springer: Berlin/Heidelberg, Germany, 1998.

47. Pavlović, I.; Kern, T.; Miklavčič, D. Comparison of paper-based and electronic data collection process in clinical trials: Costs simulation study. Contemp. Clin. Trials 2009, 30, 300-316. [CrossRef] [PubMed]

48. Sánchez González, L.; García Rubio, F.; Ruiz González, F.; Piattini Velthuis, M. Measurement in business processes: A systematic review. Bus. Process Manag. J. 2010, 16, 114-134. [CrossRef]

49. Davis, R. Aris Design Platform: Advanced Process Modelling and Administration, 1st ed.; Springer: Berlin/Heidelberg, Germany, 2008.

50. Valiris, G.; Glykas, M. Business analysis metrics for business process redesign. Bus. Process Manag. J. 2004, 10, 445-480. [CrossRef]

51. Gartner. The 2019 CIO Agenda: Securing a New Foundation for Digital Business. Available online: https://www.gartner.com/ doc/3891665/cio-agenda-securing-new-foundation (accessed on 28 March 2021).

52. Deutsche Kommission Elektrotechnik (DKE). Elektronik Informationstechnik in DIN und VDE, German Standardization Roadmap, Industrie 4.0. Available online: https:/ /www.din.de/blob/65354/57218767bd6da1927b181b9f2a0d5b39/roadmap-i4 -0-e-data.pdf (accessed on 28 March 2021).

53. Challener, C. The paint and coatings industry in the age of digitalization. Available online: https://www.paint.org/coatingstechmagazine/articles/paint-coatings-industry-age-digitalization/ (accessed on 5 July 2021).

54. Nisar, T.M.; Yeung, M. Attribution Modeling In Digital Advertising_An Empirical Investigation Of the Impact of Digital Sales Channels. J. Advert. Res. 2018, 58, 399-413. [CrossRef]

55. Bongers, F.M.; Schumann, J.H.; Schmitz, C. How the introduction of digital sales channels affects salespeople in business-tobusiness contexts: A qualitative inquiry. J. Pers. Sell. Sales Manag. 2021, 41, 150-166. [CrossRef]

56. Yan, Y.; Zhao, R.; Liu, Z. Strategic introduction of the marketplace channel under spillovers from online to ofline sales. Eur. J. Oper. Res. 2018, 267, 65-77. [CrossRef]

57. Urh, B.; Zajec, M.; Kern, T.; Krhač, E. Structural Indicators for Business Process Redesign Efficiency Assessment. In Advances in Manufacturing II-Volume 3: Quality Engineering and Management, Proceedings of the International Scientific-Technical Conference Manufacturing, Poznań, Poland, 19-22 May 2019; Hamrol, A., Grabowska, M., Maletič, D., Woll, R., Eds.; Springer: Cham, Switzerland, 2019; pp. 16-32.

58. Cheng, C. Complexity and Usability Models for Business Process Analysis. Ph.D. Thesis, The Graduate School College of Engineering, Pennsylvania State University, State College, PA, USA, 21 August 2008.

59. Cottrell, W.D. Simplified Program Evaluation and Review Technique (PERT). J. Constr. Eng. Manag. 1999, 125, 16-22. [CrossRef]

60. Ljubič, T. Operational Management of Production, 1st ed.; Modern Organization: Kranj, Slovenia, $2006 ;$ p. 25. 